\title{
GC MS/MS analysis of Bioactive Compounds in Alcoholic Seed Extract of Gauzuma ulmifolia Lam
}

\author{
Sivakami Sundari Ponnusamy*, Shanaz Banu, Murugan Vedigounder, Dhanashree Narayanswamy
}

\section{Sivakami Sundari Pon- nusamy ${ }^{1 *}$, Shanaz Banu', Murugan Vedigounder', Dhanashree Narayan- swamy}

'Department of Pharmacognosy, Dayananda Sagar College of Pharmacy, Bangalore, Karnataka, INDIA.

\section{Correspondence}

Sivakami Sundari Ponnusamy

Department of Pharmacognosy, Dayananda Sagar College of Pharmacy, Bangalore, Karnataka, INDIA.

Phone No: 8050580730

E-mail: sivakamiponnusamy@yahoo.co.in

History

- Submission Date: 20-10-2017;

- Review completed: 02-11-2017;

- Accepted Date: 20-11-2017

DOI : 10.5530/pj.2018.1.33

Article Available online http://www.phcogj.com/v10/i1

\section{Copyright}

(C) 2018 Phcog.Net. This is an openaccess article distributed under the terms of the Creative Commons Attribution 4.0 International license.

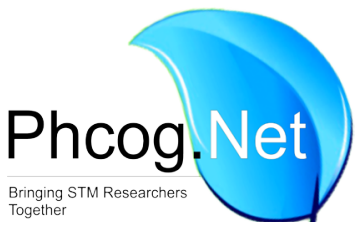

\begin{abstract}
Introduction: Gauzuma ulmifolia Lam. (GU) belonging to the family Malvaceae, commonly called Bastard Cedar is native to tropical American countries. It was introduced into India more than 100 years ago. Methods: In the present study, alcoholic seed extract of Gauzuma ulmifolia Lam. was subjected to GC MS/MS analysis and chemical compounds were characterized. Results: Totally sixteen compounds were characterized. Chemical analysis of the extract showed that it includes bioactive compounds like D-Asarinin (65.02 \%), 2,6-Bis (3,4-methylenedioxyphenyl)-3,7-dioxabicyclo (3.3.0) octane (20.12\%), 1-Dodecanone, 2-(imidazol-1-yl)-1-(4-methoxyphenyl) (7.54 \%) and o-Anisic acid, tridec-2-ynyl ester (3.33 \%) as major constituents. Minor components such as Vitamin E, $\gamma$ - Tocopherol, Ergost-5-en-3-ol, (3ß), Hexadecanoic acid, methyl ester is also present. Conclusion: Based on the above results, the seeds of this plant could posse's oxygen $(92.27 \%)$, hydrocarbon $(0.19 \%)$ and nitrogen $(7.54 \%)$ derivatives of volatile principle. This is the first-time report on the composition of seed of GU.
\end{abstract}

Key words: Gauzuma ulmifolia, Alcoholic extract, GC MS/MS analysis, D-Asarinin, Vitamin E.

\section{INTRODUCTION}

Gauzuma ulmifolia Lam. (GU) is wildly distributed in tropical America from Mexico to the northern part of Argentina and the middle part of Brazil. It has been naturalized to the local climatic conditions. This species has high economic importance. GU grows to $30 \mathrm{~m}$ in height and $30-40 \mathrm{~cm}$ in diameter with a rounded crown and drooping foliage. Bark is grey or greybrown becoming furrowed and rough with age. Young branches are covered with stellate hairs. Leaves are simple, alternate, with serrate margins, 5-7 cm long. Flowers are yellow-brown, about $1 \mathrm{~cm}$ long in $3-5 \mathrm{~cm}$ long axillary inflorescences. The fruit is a round or elliptic 5 celled capsule that opens at the apex. When the fruit is ripe, it is black and contains $40-80$ seeds, each $3-5 \mathrm{~mm}$ in diameter. There is approximately $100 \mathrm{~g}$ of clean seed in $1 \mathrm{Kg}$ of fruits and 1,50,000 clean seeds per Kg. ${ }^{1}$

The use of the plant is well documented in the traditional literature as a remedy for various ailments, such as bronchitis, burns, diarrhoea, asthma, inflammation, alopecia, diuretic, astringent and veneral diseases. ${ }^{2}$ Previous investigations of the chemical composition of GU have indicated the occurrence of flavon-3-ol procyanidins, ${ }^{2}$ nitrile and a glucoside, menisdaurin. ${ }^{8}$ This plant was reported to have anti-oxidant, ${ }^{3}$ antidiabetic, ${ }^{4,5}$ hypotensive, ${ }^{6}$ vasorelaxant, antiulcer, ${ }^{7}$ antibacterial ${ }^{9,10}$ and antiviral ${ }^{11}$ activity.
Considering all these facts, the present study was designed to investigate the presence of chemical composition of the seed extract.

\section{MATERIALS AND METHODS}

The fruits of Gauzuma ulmifolia Lam. was collected and dried at $60{ }^{\circ} \mathrm{C}$ for $24 \mathrm{hrs}$. The dried fruits were pulverized manually to remove the seeds. The seeds were purified and stored in air tight container.

The GU seed was extracted with ethanol and analyzed through Gas Chromatography- Mass Spectrometry/ Mass Spectrometry for identification of different components. ${ }^{12}$

The analyses of the alcoholic extract were run on 436-GC Bruker operating in the EI mode at $70 \mathrm{eV}$, equipped with a split/splitless injector $\left(280^{\circ} \mathrm{C}\right)$. Column BR-5MS (5\% Dimethyl polysiloxane), 30 $\mathrm{m} \times 0.2 \mathrm{~mm}$ ID $\times 0.25 \mu \mathrm{m} \mathrm{df})$. Oven temperature was programmed as follows, $110^{\circ} \mathrm{C}$ hold for 3.50 min, then increased upto $200^{\circ} \mathrm{C}$ at the rate of $10^{\circ} \mathrm{C}$ per min with no hold, then increased upto $280^{\circ} \mathrm{C}$ at the rate of $5^{\circ} \mathrm{C}$ per min for 12 min hold. Carrier gas ( $1 \mathrm{ml} / \mathrm{min}$ ), Split 10:1, Sample injected was $2 \mu \mathrm{l}$ and Injector temperature was $280^{\circ} \mathrm{C}$. Total GC running time was $40.50 \mathrm{~min}$. TQ Quadrupole Mass Spectrometer detector and Software MS Work station 8 was used for the analysis. ${ }^{11}$ 


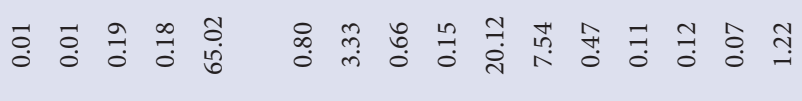

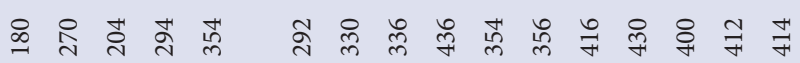

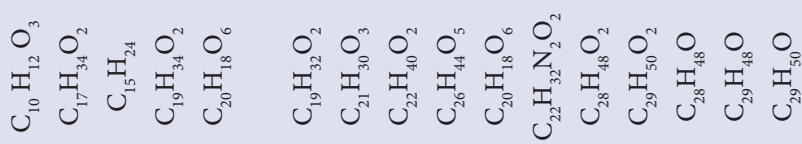
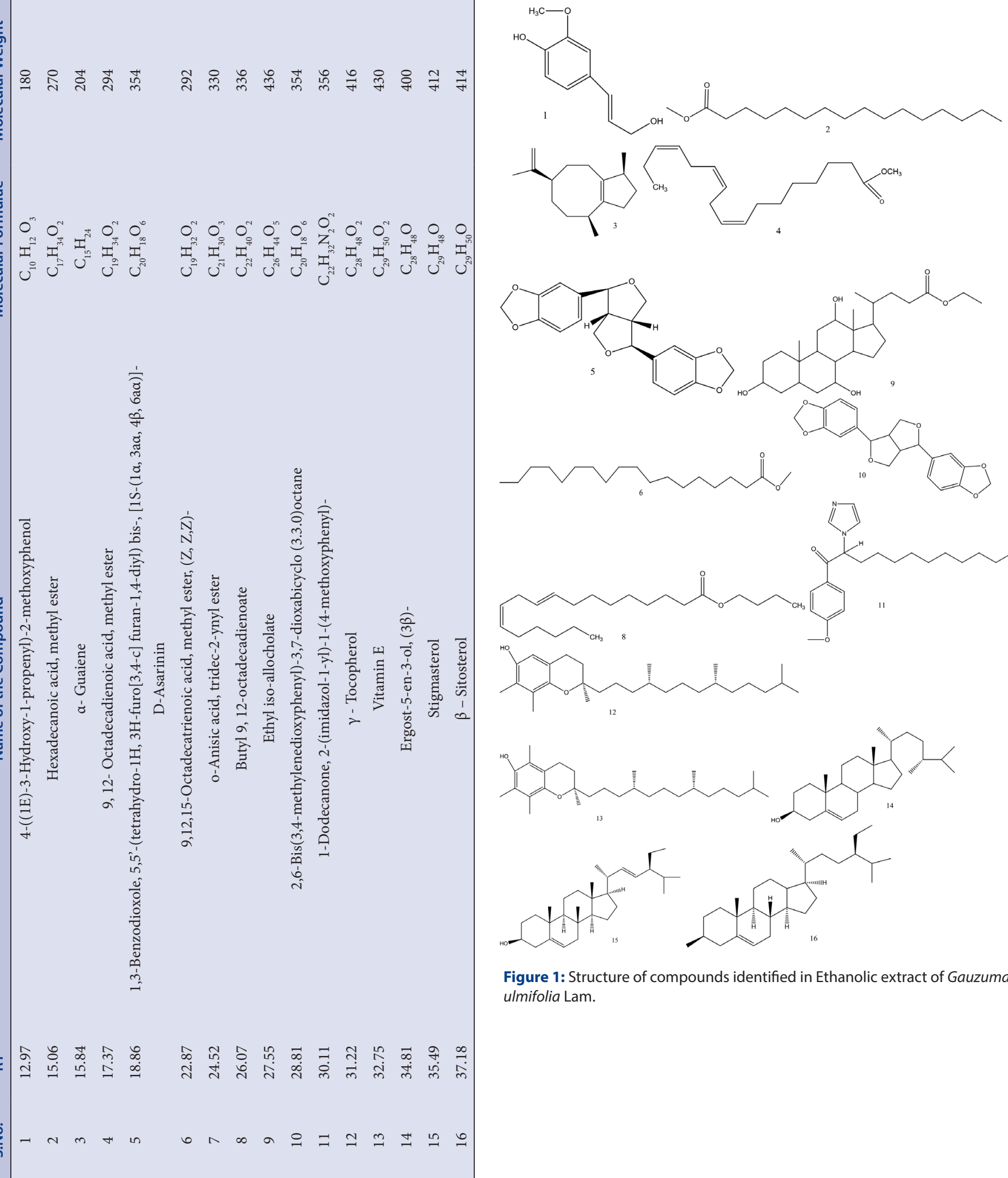


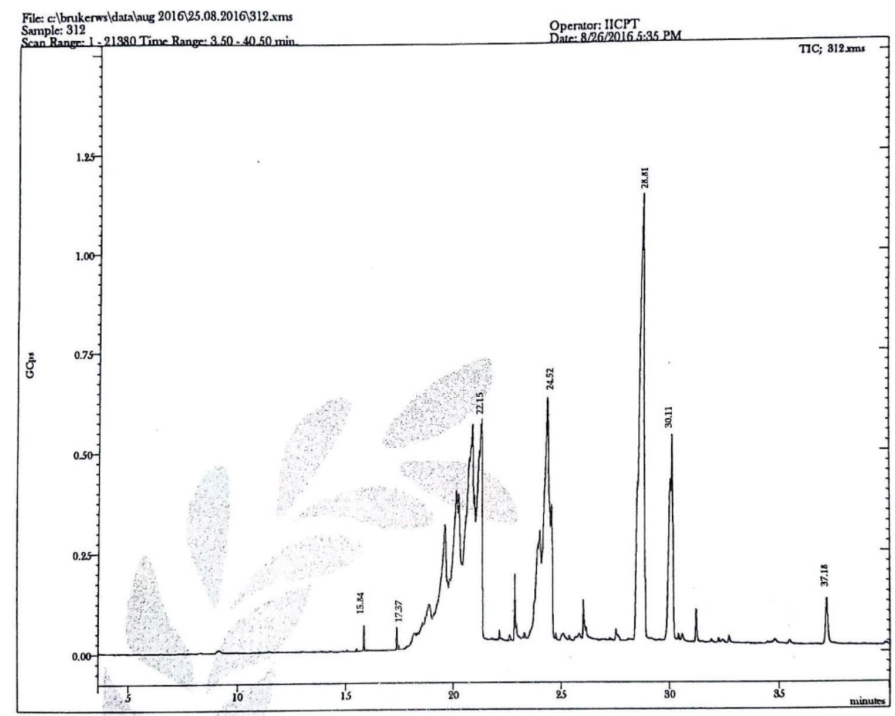

Figure 2: GC-MS/MS Chromatogram of Ethanolic extract of GU.

Library used NIST Version- 11 ; Inlet line temperature $290^{\circ} \mathrm{C}$, Source temperature $250^{\circ} \mathrm{C}$, Electron energy $70 \mathrm{eV}$, Mass scan $(\mathrm{m} / \mathrm{z}) 50-500 \mathrm{amu}$, Solvent Delay was 0 - $3.5 \mathrm{~min}$ and Total MS running time was $40.50 \mathrm{~min}$.

\section{RESULTS AND DISCUSSION}

The different compounds identified in the alcoholic extract of GU, along with their molecular formulae, molecular weight and the \% peak area are listed in Table 1. A total of 16 compounds were identified and the structures of these compounds are predicted in Figure 1. Their GC-MS/ MS chromatogram has been shown in Figure 2.

Among the various compounds identified, 2,6-Bis(3,4-methylenedioxyphenyl)-3,7-dioxabicyclo (3.3.0) octane, commonly known as D-Asarinin, Vitamin E, $\gamma$ - Tocopherol have been reported to possess antihypertensive, oxidative stress management ${ }^{13}$ and hyperlipidemic activities. ${ }^{14}$

Further, some phytosterols like Ergost-5-en-3-ol, (3ß)-, commonly known as Campesterol is known to inhibit intestinal absorption of cholesterol. ${ }^{15}$ Stigmasterol, a precursor in manufacturing of semisynthetic progesterone and vitamin $\mathrm{D}_{3}$, also an intermediate in biosynthesis of androgens, estrogens and corticoids. ${ }^{16,17} \beta$-Sitosterol, a potential dietary phytosterol for prevention and therapy for human cancer. ${ }^{18}$

\section{CONCLUSION}

The present study was focused on characterization of bioactive compounds of alcoholic extract of seeds of GU by GC MS/ MS analysis and the 16 compounds identified are responsible for the various pharmacological actions shown by GU. Therefore, the above results confirmed Gauzuma ulmifolia Lam. as a new valuable component for food and nutraceutical applications in the promotion of health.

\section{ACKNOWLEDGEMENT}

The authors wish to acknowledge Rajiv Gandhi University of Health Sciences, for providing the financial assistance to pursue the study, and extend our thanks to The Director, Indian Institute of Crop Processing Technology, Thanjavur, Tamil Nadu for GC MS/MS analysis.

\section{ABBREVIATION USED}

GU: Gauzuma ulmifolia; GC MS/MS: Gas Chromatography -Mass Spectrometry/Mass Spectrometry; m/z: Mass to charge ratio.

\section{CONFLICT OF INTEREST}

The authors declare that we do not have any conflict of interest.

\section{REFERENCE}

1. Danida Forest Seed Centre. Seed leaflet. Gauzuma ulmifolia Lam No.16. 2000.

2. Hor M, Heinrich M, Rimpler H. Proanthocyanidin polymers with antisecretory activity and proanthocyanidin oligomers from Gauzuma ulmifolia Lam bark. Phytochemistry. 1996;42(1):109-19.

3. Lopes GC, Rocha JCB, Almeida GC, Mello JCP. Condensed Tannins from the Bark of Gauzuma ulmifolia Lam. (Sterculaceae). J Braz Chem Soc. 2009;20(6):1103-9.

4. Alonso-Castro AJ, Salazar-Olivo LA. The anti-diabetic properties of Gauzuma ulmifolia Lam are mediated by the stimulation of glucose uptake in normal and diabetic adipocytes without inducing adipogenesis. J Ethnopharmacol. 2008;118(2):252-6.

5. Alarcon-Aguilara FJ, Roman-Ramos R, Perez-Gutierrez S, Aguilar-Contreras A, Contreras-Weber CC, Flores-Saenz JL. Study of the anti-hyperglycemic effect of plants used as antidiabetic. J Ethnopharmacol. 1998;61(2):101-10.

6. Magos GA, Mateos JC, Paez E, Fernandez G, Lobato C, Marquez C, et al Hypotensive and vasorelaxant effects of the procyanidin fraction from Gauzuma ulmifolia bark innormotensive and hypertensive rats. J Ethnopharmacol. 2008;117(1):58-68.

7. Berenguer B, Trabadela C, Sanchaz-FS, Quilez A, Mino P, De la Puerta R, et al. The aerial parts of Gauzuma ulmifolia Lam protect against NSAID-induced gastric lesions. J Ethnopharmacol. 2007;114(2):153-60.

8. Yoshitani S, Yoshimi F, Tabata T, HAraguchi H. Inhibitor of lipid peroxide production and composition containing the same/A lipid proxide production inhibitor containing Gauzuma ulmifolia extract. Jpn Kokai Tokkyo koho. 2000.

9. Kaneria M, Baravalia Y, Vaghasiya Y, Chanda S. Determination of antibacterial and antioxidant potential of some medicinal plants from saurashtra region, India. Indian J Pharm Sci. 2009;71(4):406-12.

10. Navarro MC, Montilla MP, Cabo MM, Galisteo M, Caceres A, Morales C, et al. Antibacterial, antiprotozoal and antioxidant activity of five plants used in Izabal for infectious diseases. Phytother Res. 2003;17(4):325-9.

11. Felipe AMM, Rincao VP, Benati FJ, Linhares REC, Galina KJ, de Toledo CEM, et al. Antiviral effect of Gauzuma ulmifolia and Stryphnodendron adstringens on poliovirus and bovine herpes virus. Biol Pharm Bull. 2006;29(6):1092-5.

12. Srinivasan K, Kumaravel S. Unraveling the Potential Phytochemical Compounds of Gymnema sylvestre through GC-MS Study. Int J Pharm Pharm Sci. $2016 ; 8(1): 1-4$

13. Noguchi J, IkedaK, Sasaki Y, Yamamoto J, Yamori Y. Effect of Vitamin E and Sessamin on hypertension and cerebral thrombogenesis in stroke-prone spontaneously hypertensive rats. 2004;31(S2):S24-6.

14. Jose LP, Anu H, Herman A. Effect of sesamin on serum cholesterol and triglycerides levels in LDL receptor deficient mice. Eur J Nutr. 2006;45(8):439-44.

15. Ikeda et al. Inhibition of cholesterol absorption in rats by plant sterols. J Lipid Res. 1988;29(12):1573-82.

16. Sundararaman P, Djerassi C. A convenient synthesis of progesterone from stigmasterol. J Org Chem. 1977;42(22):3633-4.

17. Kametani T, Furuyama $H$. Synthesis of vitamin $D_{3}$ and related conpounds. Med Res Rev. 1987;7:147-71

18. Cora JD, Bruce JG. Phytochemicals: Nutraceuticals and human health. J Sci Food Agric. 2000;80(12):1744-56. 
GRAPHICAL ABSTRACT

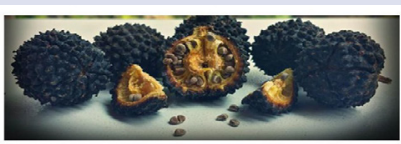

ת

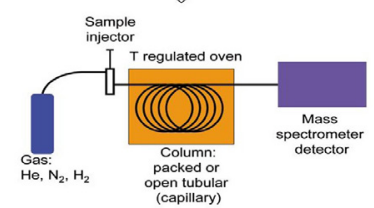

$\sqrt{1}$

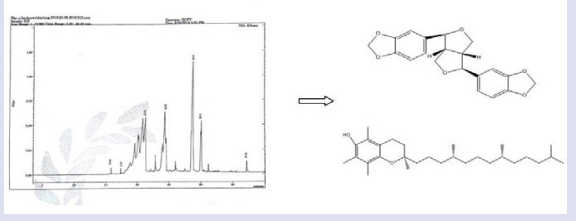

SUMMARY

- The present study has highlighted on the chemical profile of the seeds of GU for the first time by GC MS/MS method. A total of 16 compounds with their proportions have been identified. Further exploration on isolation of these phytoconstituents may develop many novel compounds with potent medicinal properties.

\section{ABOUT AUTHORS}

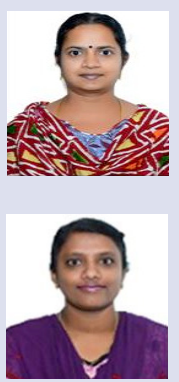

Dr.P. Sivakami Sundari, Department of pharmacognosy, Dayananda Sagar College of Pharmacy, Bangalore, India, sivakamiponnudamy@ yahoo.co.in

Dr. Shanaz Banu, Department of Pharmacognosy, Dayananda Sagar College of Pharmacy, Bangalore, India, shana2906@gmail.com

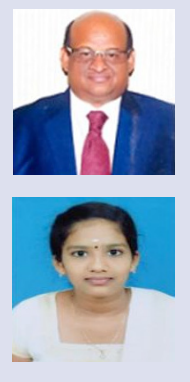

Dr. V. Murugan, Prinicipal, Dayananda Sagar College of Pharmacy, Bangalore, India, murugan_9362@yahoo.com

N. Dhanashree, Dayananda Sagar University, College of Pharmaceutical Sciences, Bangalore, India, gandhamdhanashree12@gmail.com

Cite this article: Sundari PS, Banu S, Murugan V, Dhanashree N. GC MS/MS analysis of Bioactive Compounds in Alcoholic Seed Extract of Gauzuma ulmifolia Lam. Pharmacog J. 2018;10(1):194-7. 